\title{
The Relation of IGF-1 and Insulin Resistance in a Sample of Iraqi Obese Type 2 Diabetic Patients with Macrovascular Disease
}

\author{
Bushra.F.Hasan* Isam.N.Salman** \\ Nisreen.A.Hamzah*
}

Received 25, October, 2011

Accepted 21, February, 2012

\begin{abstract}
:
Type 2 diabetes mellitus(T2DM) is a metabolic disease that is associated with an increased risk for atherosclerosis by 2-4 folds than in non- diabetics. In general population, low IGF-1 has been associated with higher prevalence of cardiovascular disease and mortality. This study aims to find out the relationship between IGF-1 level and other biochemical markers such as Homeostasis Model Assessment insulin resistance(HOMAIR) and Body Mass Index(BMI) in type 2 diabetic patients . This study includes (82) patients (40 females and 42 males) with age range (40-75) years,(34) non obese diabetic patients and (48) obese diabetic patients. The non obese individuals considered as a controls group, all controls and patients groups with type $2 \mathrm{DM}$, ischemic heart disease and hypertension, and free from other disease by history and clinical exam .The results showed that serum IGF-1 levels were lower in obese diabetic patients than non obese.HOMAIR has been found to be significantly higher in obese than non obese diabetic patients ,there is negative correlation between IGF-1 and HOMAIR. Body mass index (BMI) was in positive correlation with HOMAIR and innegativecorrelationwithIGF-1. Conclusion of this study was the serum level of IGF-1 is significantly lower in obese than non obese type 2 DM , but HOMA IR is significantly higher in obese diabetic subjects .
\end{abstract}

Key words : Insulin-like growth factor 1(IGF-1),HOMA IR ,type 2DM ,Obesity •

\section{Introduction:}

Diabetes mellitus is a group of metabolic diseases which characterized by hyperglycemia resulting from defects in insulin secretion, insulin action, or both, the chronic hyperglycemia of diabetes is associated with long-term damage, dysfunction and failure of various organs, especially the eyes, kidneys, nerves, heart, and blood vessels, that impose a tremendous burden on the individual with diabetes and on the health care system [1] .Type $2 \mathrm{DM}$ is a heterogeneous group of disorder characterized by variable degrees of insulin resistance, insulin secretion, and increased glucose production[2].Insulin resistance is an impaired response to normal levels of exogenous or endogenous insulin in cells of the whole body, thus insulin resistance has been implicated in the pathogenesis of the metabolic syndrome [3] . Obesity is a chronic disease that is casually related to serious medical illness, including T2DM [4] Which is calculated as the person's weight in kilograms divided by the squared of height in meters $\left(\mathrm{kg} / \mathrm{m}^{2}\right)[5]$. The risk to develop the

\footnotetext{
*Department of Chemistry, College of Science for Women, Baghdad University

**National Diabetes Center / AL-Mustansiriyah University
} 
disease increases strikingly if there is a family history, especially among first- degree relatives[6]. One of the major causes of insulin resistance is the overload of tissues with lipids Therefore, obesity, especially upper body obesity, physical inactivity, fat storage defects, male hormones, aging, and genetic factors may lead to the impairment of insulin action. Up to $79 \%$ of the variance in insulin sensitivity can be accounted for by central fat [7] .Ischemic heart disease or myocardial ischemia, is a disease characterized by reduced blood supply to the heart muscle, usually due to coronary artery disease (atherosclerosis of the coronary arteries) Its risk increases with age, smoking, hypercholesterolemia, diabetes, hypertension and is more common in men and those who have close relatives with ischemic heart disease[8]. Insulin -like growth factor1 it's called Somatomedin C., which is polypeptide protein hormone with high sequence similarity to insulin[9] .Its primary action is mediated by binding to specific IGF receptors present on many cell types in many tissues[9].IGF-1 receptor is heterotetramer that is homologues to the insulin receptor. It comprises two $\alpha$ and $\beta$ chains. The intracellular $\beta$ chains have tyrosine kinas activity that is activated upon ligand binding[10].The somatomedines mediate many of growth promoting effects of GH via the IGF-1 receptor which can restore growth in $\mathrm{GH}$ deficient laboratory animals [11].

\section{Materials and Methods :}

The study was conducted at National diabetes Center (NDC) /ALMustansiryah University between (Nov.2010 - March 2011). Eighty two patients were enrolled in the study with type 2 diabetes mellitus and IHD. Fourty eight patients (26 females and
22 males) were obese with mean age range (53.77 \pm 9.23$)$ years and mean BMI (34.65 \pm 4.05$)$. Thirty four patients were non obese (14females and20 males), with mean age range (57.62 \pm 7.18 )years, and mean BMI (27.61 \pm 0.88$)$, were enrolled in the study as control group. Exclusion criteria were pregnant women and those on contraceptive pills, Insulin treatment. The following biochemical investigations have been studied for their fasting plasma glucose,lipidprofile ,HbA1C ,serum IGF-1, serum Insulin ,HOMAIR,ECG, ,Blood pressure and BMI were checked, all patients and controls were with IHD and Hypertension. Total serum cholesterol was determined utilizing a readymade laboratory kit for this purpose, the principle of determination was based on the enzymatic hydrolysis .The triglycerides were determined by enzymatically hydrolyzed glycerol and fatty acids. HDL fraction which is determined by using cholesterol kit. LDL - cholesterol can be calculated mathematically from the total cholesterol, triglycerides, and the HDL - cholesterol Concentration using Friedwald's formula. VLDL concentration is calculated as one fifth of the serum TG Statistical Analysis

Student t-test and analysis of variance (ANOVA) were used to examine the degree of significant .P-value less than 0.05 considered significant .The statistical analysis was performed using the computer facility with available statistical packages SPSS 18.5 .

\section{Results:}

Data analysis showed that the levels of IGF-1 were significantly lower in obese subjects than non obese $(122.92 \pm 32.34) \mathrm{ng} / \mathrm{ml},(90.30 \pm 27.69)$ $\mathrm{ng} / \mathrm{ml}$ respectively, but insulin resistance (HOMAIR) were higher in 
obese subjects compared with non obese $\quad(6.03 \pm 3.90),(3.83 \pm 2.14)$ respectively . The mean difference in BMI was highly significant between obese and non obese diabetic patients $(34.65 \pm 4.05)$ and $(27.61 \pm 0.88)$ respectively . Analysis of lipid profile showed no significant mean value of cholesterol between obese $(182.42 \pm 54.88) \mathrm{mg} / \mathrm{dl}$, and non obese $(163.47 \pm 50.06) \mathrm{mg} / \mathrm{dl}$ diabetic patients. Also there was no significant mean difference of TG between obese $(162.25 \pm 103.86) \mathrm{mg} / \mathrm{dl}$ and non obese $(160.91 \pm 79.62) \mathrm{mg} / \mathrm{dl}$. There is no significant mean difference of HDL in obese $(43.17 \pm 6.40) \mathrm{mg} / \mathrm{dl}$ and non obese diabetic $(45.41 \pm 8.23)$ $\mathrm{mg} / \mathrm{dl}$, and no significant mean difference of LDL in obese $(104.79 \pm 53.42) \mathrm{mg} / \mathrm{dl}$ and non obese $(86.59 \pm 51.04) \quad \mathrm{mg} / \mathrm{dl}$.There was significant mean difference of VLDL between obese $(39.25 \pm 20.73) \mathrm{mg} / \mathrm{dl}$ and non obese $(32.47 \pm 15.83) \mathrm{mg} / \mathrm{dl}$ Our study showed that inverse relationship between IGF-1 and HOMAIR $r=-0.630$ in obese diabetic patients and negative correlation between IGF-1 and BMI $r=-0.613$ in obese subjects ,but there was positive correlation between HOMAIR and BMI as shown in (Table -1).

(Table-1)The correlation coefficient of IGF-1with different parameters.

\begin{tabular}{|c|c|c|}
\hline & \multicolumn{2}{|c|}{ IGF-1 (ng/ml) } \\
\hline & $\begin{array}{l}\text { Obese } \\
\text { T2DM }\end{array}$ & $\begin{array}{c}\text { Non-Obese } \\
\text { T2DM }\end{array}$ \\
\hline Age (years) & $0.347 *$ & 0.169 \\
\hline Height $(\mathbf{c m})$ & $0.286 *$ & 0.026 \\
\hline Weight (Kg) & -0.224 & -0.202 \\
\hline BMI $(\mathrm{Kg} / \mathrm{m} 2)$ & $-0.613 * *$ & $-0.809 * *$ \\
\hline $\begin{array}{c}\text { Fasting blood glucose } \\
(\mathrm{mmol} / \mathrm{l})\end{array}$ & $-0.452 * *$ & -0.277 \\
\hline HbA1c\% & $-0.297 *$ & -0.076 \\
\hline Cholesterol (mg/dL) & 0.064 & 0.272 \\
\hline Triglyceride (mg/dL) & $-0.369 * *$ & -0.085 \\
\hline HDL (mg/dL) & 0.159 & 0.099 \\
\hline $\mathbf{L D L}(\mathbf{m g} / \mathbf{d L})$ & 0.192 & 0.253 \\
\hline VLDL (mg/dL) & $-0.392 * *$ & -0.074 \\
\hline Insulin level $(\mu \mathrm{IU} / \mathrm{ml})$ & $-0.509 * *$ & $-0.575 * *$ \\
\hline HOMA IR & $-0.630 * *$ & $-0.708 * *$ \\
\hline
\end{tabular}

*Correlation is significant at 0.05 level

**Correlation is highly significant at 0.01 level

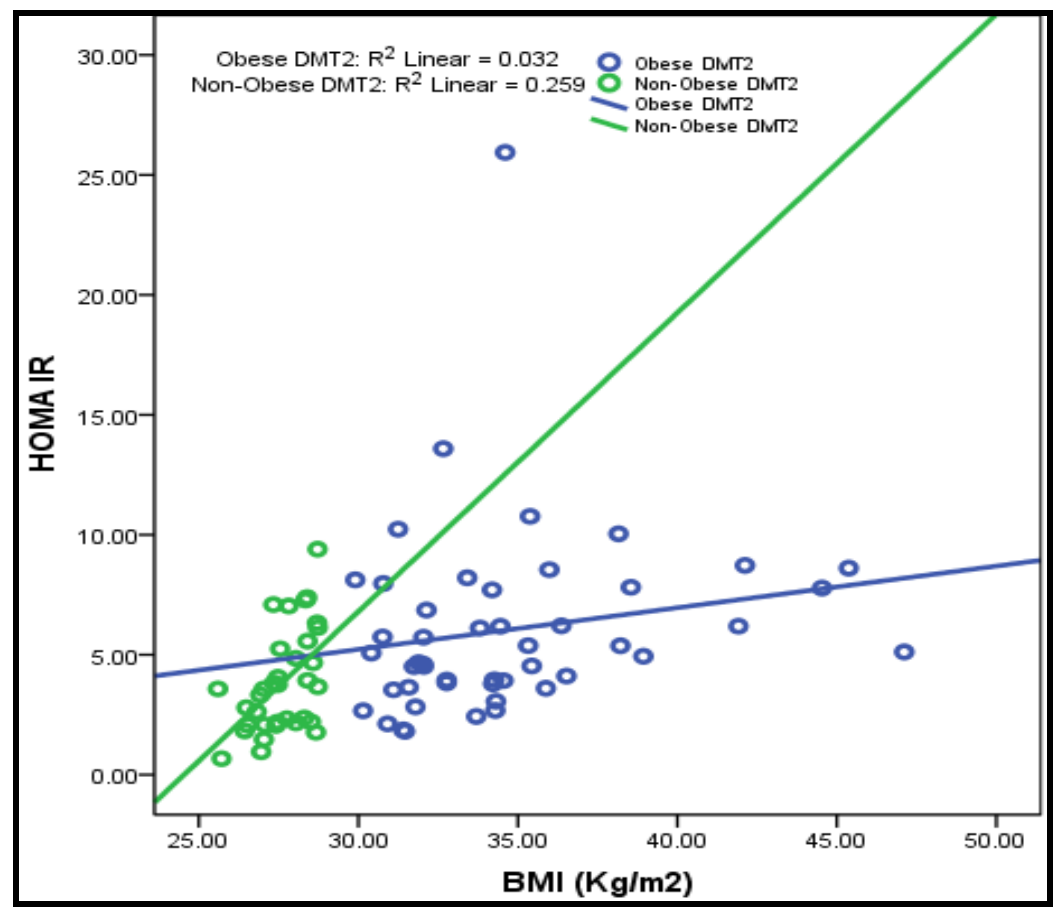

(Figure-1) :The correlation between HOMAIR and BMI 


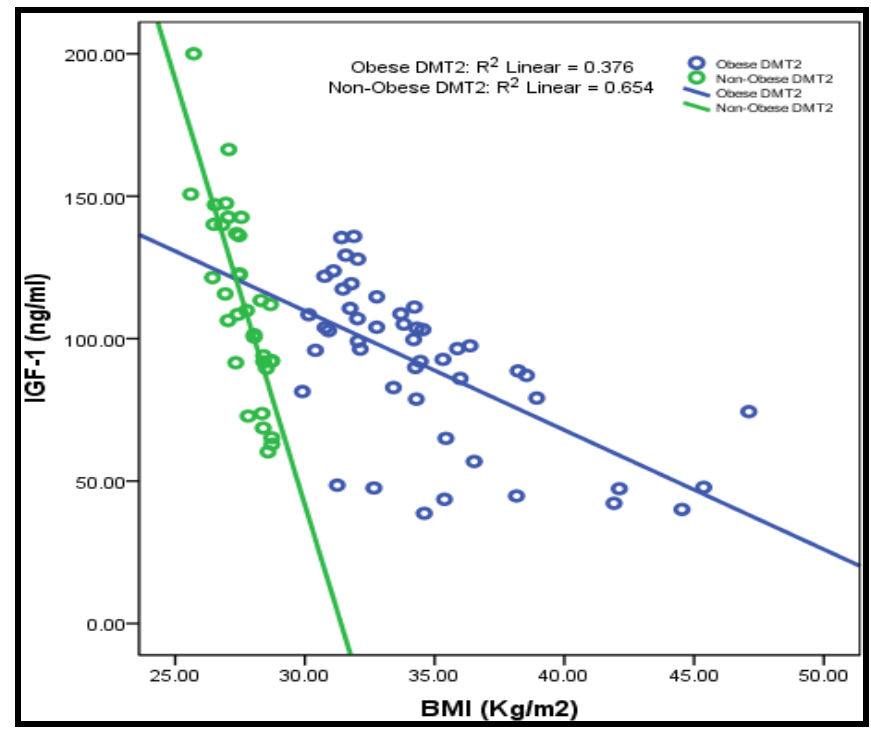

(Figure-2) :The correlation between IGF-1 and BMI

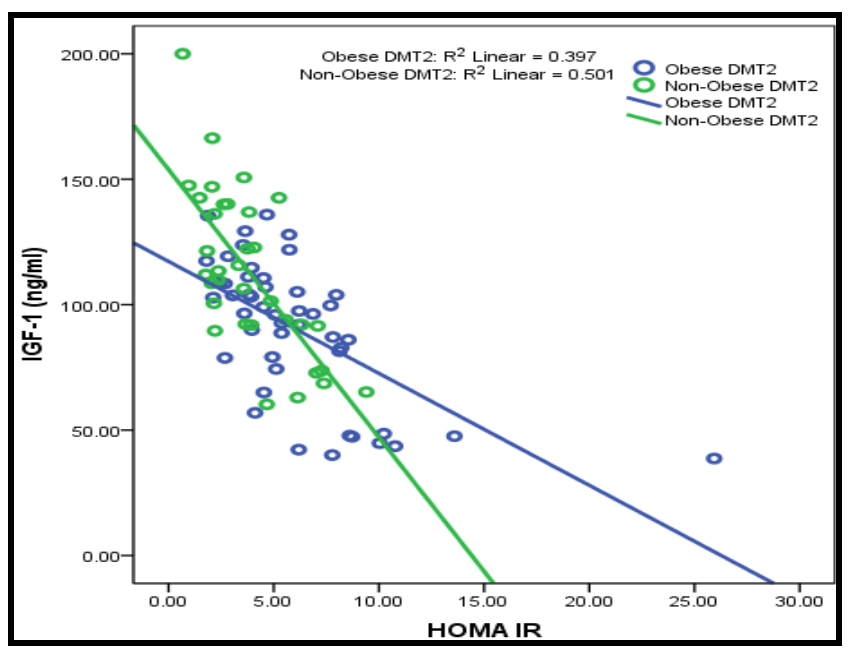

Figure-3):The correlation between IGF-1 and HOMAIR(

\section{Discussion:}

The present study showed that patients with obesity have a high level of insulin résistance, the mean of HOMAIR was high in obese diabetic patients. The development of obesity involves the expansion of the adipose tissue at the expense of a combined process involving proliferation and differentiation of new adipocytes and enlargement of older adipocytes[12,13]. Samin et al. [14]; studied that IGF-1 concentrations were significantly lower with increase obesity (BMI $\geq 35$ ), which is in agreement with our results which showed that obese patients have lower level of IGF-1 when the BMI is increase .The present study demonstrated a statistically significantly low level of IGF-1 in patients with obesity compared with control (non obese) subjects ,but Nam SY and Lee EJ [15]; studies suggested that IGF-1 is increased with increase degree of obesity and this may be also explained by the hyperinsulinaemia associated with obesity[16], and insulin may increase hepatic IGF-1 production [17]. Serum level of IGF-1 of both obese and non obese diabetic are negatively correlated with insulin resistance. 
IGF-1 level is significantly lower in obese diabetic patients ,but negatively correlated with BMI in both groups .These results collectively support the hypothesis that hyperinsulemia may contribute to insulin resistance in obesity. However diabetes and obesity had significant and independent effects on IGF-1, thus the negative relationship between serum IGF-1 and diabetes was not totally explained by the presence of obesity [18,19] .Bjarnegard et al. [20];reports suggested that the diabetes mellitus had decreased serum levels of IGF-1 [21]. Martha et al. ;studied that fasting serum IGF-I concentrations were negatively correlated with fasting plasma glucose, insulin, triglycerides, total LDL and VLDL cholesterol, homeostatic model assessment of insulin resistance (HOMA-IR), and age. Fasting serum IGF-I concentrations were positively correlated with fasting HDL cholesterol and homeostatic model assessment of insulin sensitivity (HOMA-S) in only diabetic subjects[22].Rasmussen et al (2007); demonstrated that IGF-1 promoter polymorphism leading to a moderate reduction in circulating IGF-1, and leads to an increased risk of acute myocardial infaraction .There remains a controversy regarding the effect of obesity on circulating IGF-1 concentrations. Some studies have shown a reduction in IGF-1 concentrations in obese diabetic patients and this is in agreements with our study which showed that patient with risk increased cardiovascular disease (CVD)are obese and have low level of IGF-1[23]. This study agreed with Patel et al (2001); study who showed that in advanced atherosclerotic plaques,IGF-1 and IGF-IR expression are significantly reduced, and this is thought to contribute to plaque instability[24]. Langhlin et al. (2004); also demonstrated that individuals without coronary artery disease, but with low serum IGF-1 had twice risk of developing coronary artery disease during 5-year follow up. With this, the Roncho Bernardo study showed that in older adults each $40 \mathrm{ng} / \mathrm{ml}$ decrement in IGF-1 level was associated with an increment of $38 \%$ in the risk of coronary artery disease mortality[25]. This is in agreement with our study which had showed that serum IGF-1 level is significantly lower in obese type $2 \mathrm{DM}$ in comparism with non obese . Colao et al. (2008); suggested that free IGF-1 levels a protective role in the development of atherosclerosis. However ,the consistency that has been seen in the link between type 2 diabetes and IGF-1 levels has not been seen reviewing the literature concerning the link between type 1 diabetes and IGF-1 levels .One study contributes that the discrepancy may be due to differences in assay technologies [26] .

\section{References:}

1.American Diabetes Association. (2008). Diagnosis and classification of Diabetes mellitus, Diabetes Care. 31 (suppl.1): S55- 60.

2. Power, A. C. (2006). Diabetes Mellitus. In: Kasper, D. L., Fauci, A. S., Braunwald, E., Hauser, S. L., longo, D. L. and Jameson, J. L. eds . "Harrison's Endocrinology". 16 ${ }^{\text {th }} \mathrm{ed}$., New York, Mc Graw - Hill Co., pp 283-284.

3. Reaven, G.M. (2005). Insulin resistance, the insulin resistance syndrome, and cardiovascular disease,Panminerva Med.47(4):201210.

4.Gallagher, D., Heymsfield, S.B. \& Heo M. (2000). Health percentage body fat ranges, an approach for developing 
guidelines based on body mass index,Am J Clin Nutr. 72: 694-701.

5. Hanlon, P., Byers, M., Walker, B. R. and Summerton, C. (2006).Environmental and nutritional factors in disease. Part 1. In: Boon, N. A., Colledge, N. R., Walker, B. R. and Hunter, J. A. A. eds. "Davidson's Principles and practice of Medicine". $20^{\text {th }}$ ed., Edinburg, Churchill Livingstone., pp 113.

6. Lyssenko, V., Jonsson, A. and Almgren, P. et. al. (2008). Clinical risk factors, DNA. Variants, and the development of type 2 diabetes, The New England Journal of Medicine. 359 (21): 2220-32.

7. Han, T.S., Williams, K., Sattar, N., Hunt, K.J., Lean, M.E., Haffner, S.M. (2002). Analysis of obesity and hyperinsulinemia in the development of metabolic syndrome: San Antonio Heart Study,Obes Res.10:923-931.

8.Loria, V., Dato, I., Graziani ,F., Biasucci ,LM . (2008). Myeloperoxidase: a new biomarker of inflammation in ischemic heart disease and acute coronary syndromes, Mediators Inflamm. 135625.

9. Bulter ,AA., Yakar, S., Le Roith D. (2002). Insulin-like growth factor1:compartmentalization with the somatotropic axis, News physiol.Sci. 17:82-5.

10. Yakar ,S. et al. (2004). Inhibition of growth hormone action improves insulin sensitivity in liver IGF-1-deficient mice,J. Clin. Invese. 113:96-105.

11. Wolpin, B. M., Michaud ,D. S., Giovannucci, E. L., Schernhammer E. S.,et al. .(2007). Circulating Insulin-Like Growth Factor Binding Protein-1 and the Risk of Pancreatic Cancer, Cancer Res. August 15; 67(16): 7923 - 7928.

12.Gregoire, FM., Smas ,CM., Sul H.(1998).Understanding adipocyte differentiation,Physiol Rev. 78:783-809

13.Hausman ,DB., DiGirolamo, M., Bartness, TJ., Hausman, GJ., Martin,RJ. (2001). The biology of white adipocyte proliferation, Obese Rev. 2:239-254 .

14. Samin Moham, RD. (2010). The effects of obesity on the relationships among insulin like growth factor- 1 and markers of diabetes ,A thesis Submitted to the Graduate College of Bowling Green State University,In partial fulfillment of the requirements for the degree of Master of Family and Consumer Sciences .

15. Nam,SY., Lee,EJ., Kim,KR. (1997). Effect of obesity on total and free insulinlike growth factor(IGF-1), and their relationship to IGF-binding protein (BP)1,IGFBP-2,IGFBP-3,insulin, and growth hormone,Int J Obese .21:355-9.

16.Defronzo ,RA., Ferrannini, E. (1991). Insulin resistance.Amultifaceted syndrome responsible for NIDDM ,obesity,hypertension,dyslipidemia ,and atherosclerotic cardiovascular disease ,Diabetes Care .14 :173-194

17.Froesch, ER., Guler, HP., Schmid,C., Zapf,J. (1990). Therapeutic potential of insulin-like growth factor 1,Trends Endocrinology Metab.1:254-260

18. Berrigan, D., Potischman, N., Dodd ,KW., Hursting, SD., Lavigne, J., Barrett ,JC., et al. (2009). Race/ethnic variation in serum levels of IGF-I and IGFBP-3 in US adults, Growth Horm.IGF Res.19(2):146-155.

19. Clemmons,DR., Underwood, LE. (1991). Nutritional regulation of IGF$\mathrm{I}$ and IGF binding proteins, Annu.Rev.Nutr.11:393-412.

20. Bjarnegård, Niclas, Hans J Arnqvist, Torbjö;rn Lindströ;m, Lena Jonasson and Toste Länmen. (2009). Longterm hyperglycaemia impairs vascular smooth muscle cell function in with type 1 diabetes mellitus women, Diabetes and Vascular Disease Res. 6: 25 .

21. Hedman, C., Frystyk, J., Lindström, T.(2004). Residual $\beta$-cell function more than glycemic control determines abnormalities of the insulin-like growth factor system in type 1 diabetes,J Clin Endocrinol Metab. 89:6305-09.

22. Martha, S., Pantam, N,T hungathurthis, Rao VL., Devarakonda K. (2008). Study of insulin resistance in relation to serum IGF-1 levels in subjects with different degrees of 
glucose tolerance, Int J Diabetes Dev Ctries.28(2):54-9.

23. Rasmussen ,MH., Juul, A., Hilsted ,J . (2007). Effect of weight loss on free insulin-like growth factor -1 in obese women with hyposomatotropism,Obesity (Silver Spring) 15:879-886.

24. Patel, VA., Zhang, QJ., Siddle ,K., Soos, MA., Goddard, M., Wessbery, PL., Bennett ,MR. (2001). Defect in insulin-like growth factor-1 survival mechanisms in atherosclerotic plaque derived vascular smooth muscle cells is mediated by reduced surface binding and signaling,Circ Res.88:895-902.
25. Langhlin, GA., Barrett-Connor, E., Criqui,MH., Kritz-Silverstien, D. (2004). The prospective association of serum insulin like growth factor 1 (IGF-1) and IGF-1 binding protein-1 levels will all cause and cardiovascular disease mortality in order adults the Rancho Bernardo study,Clin Endocrinal Metab.89:114-120

26. Colao ,A., Di Somma ,C., Cascella, T., Pivonello ,R., Vitale, G., Grasso ,LFS.,et al. (2008). Relationships between serum IGF1 levels, blood pressure, and glucose tolerance: an observational, exploratory study in 404 subjects,Eur.J.Endocrinol. 159(4):389397.

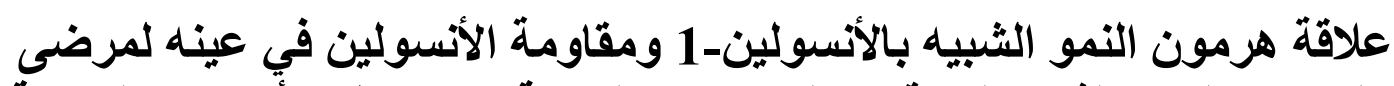

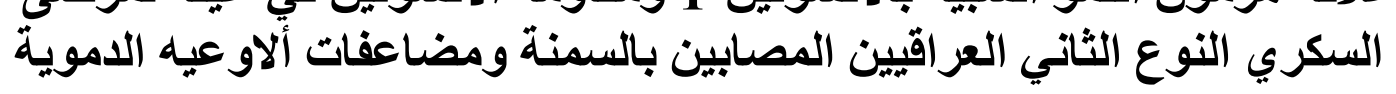
عصام نوري سلمان** نسرين أحد حمزة*

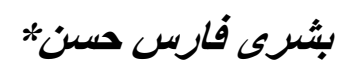

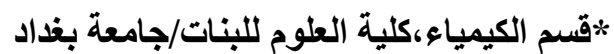 \\ *:المركز الوطني لعلاج وبحوث السكري/الجامعة المستنصرية
}

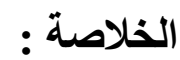

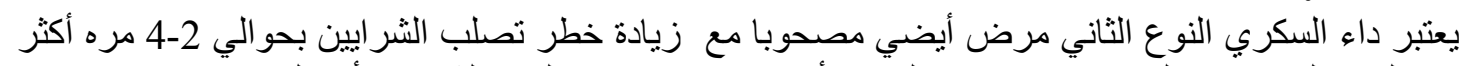

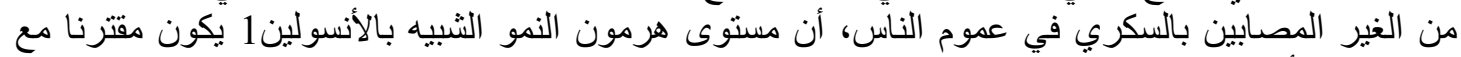

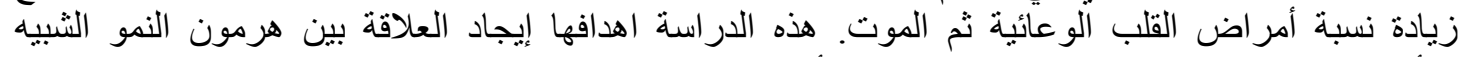

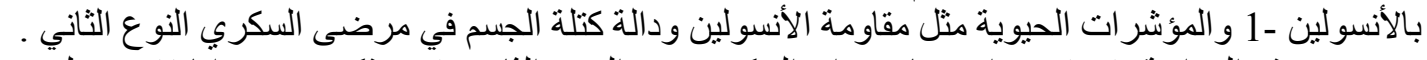

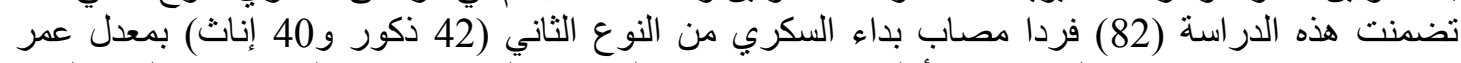

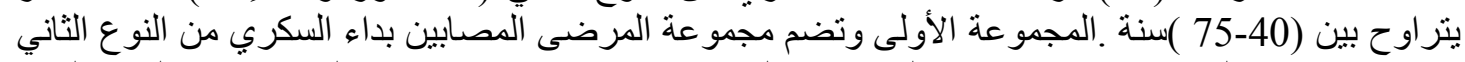

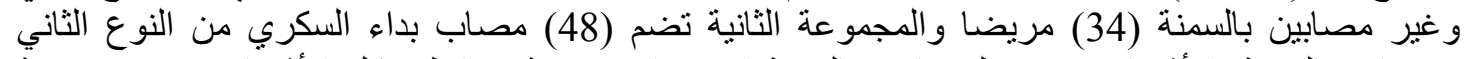

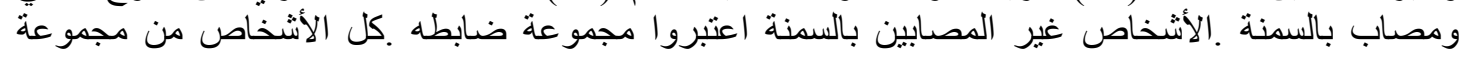

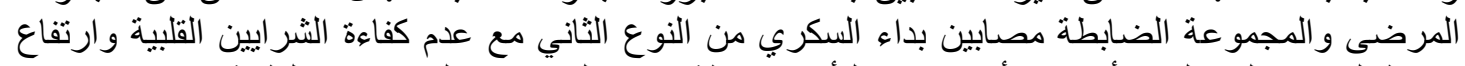

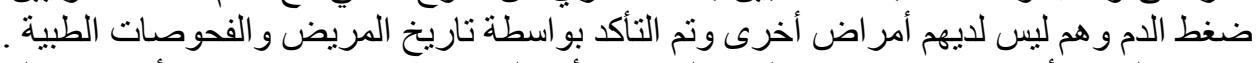

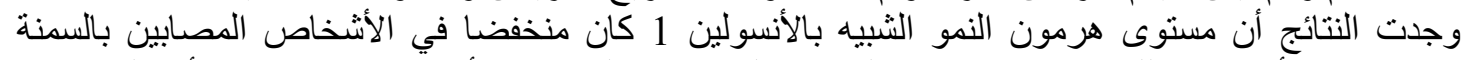

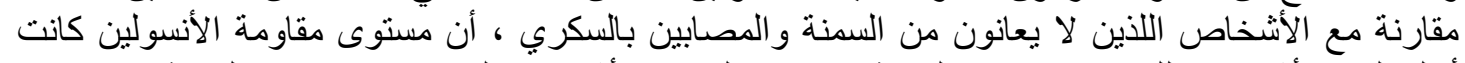

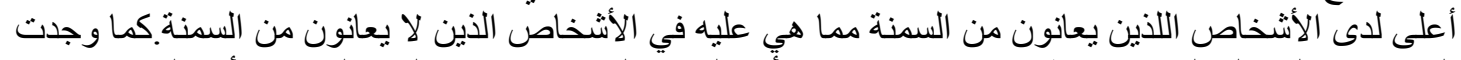

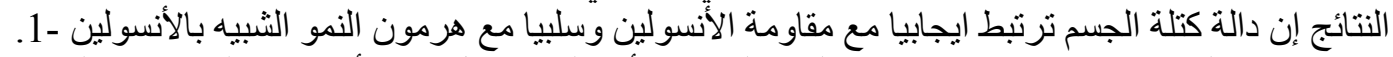

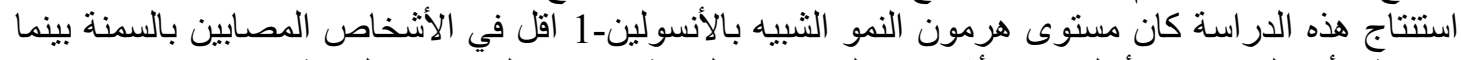

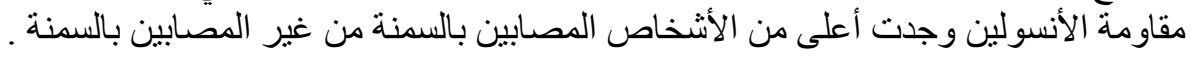

